\title{
Manpower Crunch: A Study of Hospitality Industry in India
}

* Dr. Tripti Barthwal (Professor)

${ }^{* *}$ Ms. Akanksha Srivastava (Research Scholar)

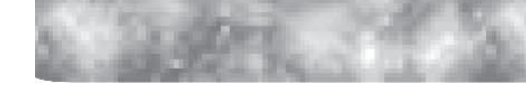

\author{
Effulgence \\ Vol. 10 No. 2 \\ July - December, 2012 \\ Rukmini Devi Institute of Advanced Studies \\ E-mail : effulgence@rdias.ac.in, Website : www.rdias.ac.in \\ http://effulgence.rdias.ac.in/user/default.aspX \\ https:/ / dx.doi.org/10.33601/effulgence.rdias/v10/i2/2012/49-54
}

\begin{abstract}
The Indian Hospitality Industry is booming with major Hotel brands knocking the doors of India. As the tourism industry is booming, the hotel industry is facing major shortage of manpower, in the hotel industry. Even though the dreaded word "Recession" is resurfacing now and then the Indian Hospitality is not bothered. In the bighly globalized world, where growing middle class dictates the many dynamics of ever growing economy, the hospitality industry has been witnessing immense growth. Supported by increased inflow of tourists, various grown drivers like development of key infrastructure and many government initiatives in Indian tourism sector, the Indian hospitality industry is expected to take off in a big way. The paper deals with the growth in hospitality industry, reason of manpower shortage in hospitality industry, challenges and opportunities in hospitality industry, few expert's comments on the issue and then recommendations to hospitality industry and hospitality institutions.
\end{abstract}

Key Words: Manpower Crunch, Hospitality Industry, Foreign Tourist, Demand \& Supply of manpower.

\section{INTRODUCTION}

$\mathrm{T}$ he Indian hospitality industry is booming with major hotel brands out to cash in on the tourism boom but the industry is facing a serious manpower crunch. The dreadful recession clouds have given way to sunny rays of economic boom, bringing glee to the faces of the votaries and the one sector that has been riding on this resurgent boom is tourism and hospitality sector. In a globalized world, where a growing middle-class dictates the many dynamics of an ever-growing economy, the hospitality sector has been witnessing immense growth. Buoyed by increased inflow of tourists, various growth drivers, development of key infrastructure facilities and the government's many initiatives in the tourism sector, the Indian hospitality industry is all set to take the next big leap.

\section{GROWTH IN INDIAN HOSPITALITY INDUSTRY}

(INSERT FIGURE 1 HERE)

From figure 1, it is analysed that there is a regular growth in Indian hospitality industry. The most rush month is February and in this month there was 5.5 lakh foreign tourist and in 2010 there was 6 lakh foreign tourist and in
2011 there was 7 lakh foreign tourist in India. So there is a continuous growth in Indian hospitality industry year by year.

\section{World Economic Forum: Travel and Tourism Competitiveness Report 2011}

According to the Travel and Tourism Competitiveness Report 2011 by the World Economic Forum, refer (table 1), India is currently ranked 12 th in the Asia Pacific region and 68th overall in the list of the world's attractive destinations.

\section{(INSERT TABLE 1 HERE)}

As per consulting firm Cygnus's report, by 2015 the Indian hotel industry is expected to reach Rs 230 billion, growing at a robust CAGR of 12.2 percent. India will be investing around Rs 448 billion in the hospitality industry in the next five years.

Statistics also show that the total number of hotel rooms in India will reach more than 180,000 within five years. Around 40 international brands are all set to foray into the lucrative and promising Indian hospitality segment. Estimates put the hotel room market for the 10 largest Indian metros at an annual growth rate of 17 per cent to $\$ 2.66$ billion by 2013 . 
Well, everything looks so hunky dory and smooth but there is a serious hitch here. Where are the butlers and chefs to man this burgeoning number of hotels? Will there be enough, qualified and competent manpower in line with the boom in the hospitality industry? Will the current institutes be able to keep pace with the ever-growing demand?

Despite all the lofty talks about the booming hospitality industry and the perceived glamour tag attached to it, there is still an air of jinx about the whole sector with the dignity of labour playing havoc. Even in the modish career-talk, hospitality industry is a least desired one; it is being relegated for the 'subaltern' tribe. In a nutshell, the Indian middleclass is yet to consider a career in the service industry as a best option. So there has to be drastic change in mindset among the young talent. The problem is graduates prefer sectors like retail, BPO, etc that fetch them fast bucks. And last but not least is the issue of long working hours and low pay packages.

Voyager's World talked to a couple of industry insiders/experts in this regard. While everyone agrees to a manpower shortage, majority was averse to the idea of government intervention. There is also near unanimity in the opinion that long working hours and relatively low pay packages are deterrents and most importantly, the quality of the hotel management courses leaves much to be desired. Research says majority of the students coming out of the hotel management institutes are not even hireable.

\section{(INSERT TABLE 2 HERE)}

From table 2, the additional hotel manpower required in the next ten years, it does not appear to be an ambitious number. It is essentially 21,200 people a year. According to the All India Council for Technical Education (AICTE), India has roundly 140 approved hotel management institutes. Factoring in the permissible intake for each institute, there are about 10,000 students graduating with either a degree or diploma in hospitality ever year. Not only does this number fall significantly short of the annual demand for hotel manpower, but also not all 10,000 new graduates have the desired skill set and, in fact, many are not even considered hireable by most hotel companies. A number of graduates also get hired by retail companies and travel agencies and by the airline and business process outsourcing industries. There are, thus, the following concerns: are the existing hotel management institutes doing enough to ensure that their students graduate with the expected entry-level skills and training? Does the industry, to begin with, have enough qualified and experienced teaching staff and up-to-date training facilities, technologies and material? Are the freshout-of-school graduates armed with all the tools and soft skills necessary in a rapidly-evolving, fast-growing industry? The shortfall is on all levels and not just in the absolute number of graduates that the country is producing. This discrepancy in the expected and the actual level of skill set poses as a significant problem for Human Resource executives. Due to an insufficient skill set to begin with, new recruits struggle to develop the required skill set to move up to mid-level and/or high-level executive positions. Essentially, this leads to a small talent pool for HR managers to poach from for senior level positions.

It is safe to say, that the industry almost needs two types of schools to cater to the impending demand;

1) A skills-oriented training academy.

2) A high quality managerial academy.

The availability of skilled and trained manpower is a crucial element in the successful long-term development and sustainability of a tourist destination. Needless to say, there is dire need for better trained and qualified graduates to enter the industry in order to meet the manpower requirement by 2021 .

\section{CHALLENGES IN HOSPITALITY INDUSTRY}

Experts have identified following major challenges in the hospitality Industry :-

- Long working hours and relatively low pay package.

- Poor quality of hotel management courses, student passing out of the hotel management industry are not hireable or deployable into the industry at various levels. Most of the training institutes do not have proper infrastructure and experience trainers and consultants

- Inability of the hotels to retain trained and quality manpower

- The issue of lateral or vertical growth opportunities, and proper career development plan does not exists in most of the hotels, for their employees.

- Whatever the glamour the industry offers the biggest issue are "Dignity of labour", "work environment", "work life balance", "stay environment" and "the pay package"

- To sustain growth in the travel and tourism industry, trained manpower/ workforce is required at every level - managerial, supervisory, skilled or semi-skilled. Challenges faced at each level are different.

- Service level: In addition to tour operators and hotel staff, tourists interact with persons from different backgrounds, occupations and experience. Such people include staff at bus/railway station, immigration staff at 
airports, taxi/coach operators, ticketing/ travel agencies, small hotels, dhabas/roadside eateries, staff at heritage sites, and tour guides, among others. The degree of service offered by these various stakeholders has a significant impact on determining the tourist's overall experience of India as a tourist destination.

\section{OPPORTUNITIES IN HOSPITALITY INDUSTRY}

In India because of lots of factors there is a huge opportunity in hospitality industry.

Diversity in India: India's size and massive natural, geographic, cultural and artistic diversity offers enormous opportunities for the travel and tourism industry. The promotion and aggressive marketing measures undertaken by the government is expected to aid influx of tourists. The industry would also benefit from introduction of new forms of tourism and development of niche segments.

Medical tourism: In India medical tourism has gained considerable popularity in recent years. India has a major cost advantage in this field compared with other countries. In addition to cost advantages, Indian healthcare industry offers state-of-art equipment, technological advancement, qualified and experienced medical personnel and a blend of modern and traditional medicines. Thus, medical tourism has immense potential in India.

Ecotourism: Opportunities also exist in ecotourism, adventure tourism, and cruise tourism. Eco-tourism is increasing in popularity, evident in the development of ecofriendly hotels and tour packages. With increasing environment awareness and consciousness among tourists and given efforts undertaken by the government and private players, the ecotourism segment is expected to record handsome growth in the coming years.

Adventure \& Cruise Tourism: India holds immense potential in adventure and cruise tourism. India's greatest adventure tourism assets are Himalayas and its mighty rivers. The peak period for adventure tourism is the "lean period" of cultural tourism. Development of adventure tourism can make India a round-the-year tourist destination. The cruise industry is one of the most promising industries in India. However, strong efforts need to be made to develop this industry. Other forms of tourism such as agri tourism, pilgrimage tourism, heritage tourism, and MICE tourism also hold enormous potential.

\section{RECOMMENDATIONS}

\section{Recommendations to Hospitality industry}

Tie-ups with Institutes: It is the duty of the Industry to make necessary tie-up/arrangement for their required human resources with one or two hospitality institutes in the country.

Continuous Training: There is a need of continuous training to all categories of employees in the organization. When they have a tie-up with the institutes, the institutes will offer in -house training to different category of employees from time to time to update their skills.

Sponsoring: It is the duty of the industry to sponsor some amount / equipment to the institute for their betterment. If possible they sponsor a chair for continuous funding and research for that institute.

Research: Every institute should spend some amount for the research which is essential for further development and understand the present situation. The industry should involve in the researchers by providing timely information and data which is ultimately useful for them only.

\section{Recommendations to Hospitality Institutes (Academic)}

Industry institute interface/interaction: Every institute must make necessary tie-ups with hotel/tourism industry for providing employment to their students.

Arranging guest lectures from industry: The management of the institutes must arrange guest lectures/visiting faculty from the industry to give complete industry information to the students about the industry and its developments.

Visits to hotels (students): The institutes should arrange field visits and training in star hotels for their final year students.

Nominating the industry people: Every institute must nominate one or two people from industry in their advisory body for the betterment of students.

Revise the curriculum: It is the duty of the institute to revise the curriculum as per the industry needs from time to time. 
Pay good salaries to trained staff: Several educational institutions are offering very low salaries to their teaching staff, this influence the quality of teaching and there by it produces inferior quality managers which indirectly created unemployment though there is a demand in the industry.

\section{CONCLUSION}

Travel and Tourism Competitiveness Report 2011 by the World Economic Forum, India is currently ranked 12th in the Asia Pacific region and 68th overall in the list of the world's attractive destinations. According to the collected data it is predicted that there is a huge shortage of trained professionals every year with the flourishing of hotels. So there is a big opportunity in this industry but on the other side the mindset of Indian middle class is that they don't appreciate hospitality industry as their career option. One more important point which should be noticed that hospitality institution's course curriculum should be according to the demand of the industry and they should emphasize more on practical aspect so that they can provide the competent manpower to the industry. Industry should also take few initiatives to make this field an attractive career option like better pay/packages, career growth opportunities, healthy work environment, work life balance etc.

\section{REFERENCES}

1. Batra G.S., Tourism in the $21^{\text {st }}$ century, 1996 Anmol publications Pvt. Ltd.,.245 Pgs

2. Federation of Hotels \& Restaurants Association of India ltd, www.fhrai.com,

3. Investment opportunities in Tourism Sector, Government of India portal Investment Commission http://www.investmentcommission.in/tourism.htm\#v

4. Jithendran K.J \& Tom Baum, 2000, Human Resource Development and Sustainability - the case of Indian Tourism, International Journal of Tourism Research, Vol.2, Issue 6, pp 403-421

5. Khanna, M.K, 1999, Human Resource Development requirements of the tourism sector in India, UNESCAP ref.No.ST/ESCAP/2020.

6. Manpower Recruitment in Hotel industry, A market plus report of Ministry of tourism, Government of India.

Effulgence, Vol. 10, No. 2, July - December, 2012
7. Swain, Sampad Kumar, 2007, Human Resource Development in Indian Tourism, Abhijit Publications. New Delhi

8. Http://www.voyagersworld.in/content/manpowercrunch-hospitality-industry

9. Http://www.thehindubusinessline.in/bline/2008/ 01/22/stories/ 2008012251311200.htm

10. Http://www.business-standard.com/india/ news/quality-manpower-shortage-big-blow-tobooming-hotel-industry/436087/

11. Http://m.economictimes.com/PDAET/articleshow/ msid-9058478, curpg-2.cms

12. Http://indiahospitalitynews.com/?p=380

13. Http://www.indianmanpower.com/imr-hospitalitypersonnel.htm

14. Http://www.voanews.com/english/news/a-13-200807-11-voa26-66822597.html

15. Http://articles.economictimes.indiatimes.com/2011-0701/news/29726257_1_hotel-management-hotelindustry-hotel-boom

16. Http://economictimes.indiatimes.com/manpowercrunch-plagues-hospitality-industry/articleshow/ 9058507.cmsv

17. Http://www.business-standard.com/india/news/ quality-manpower-shortage-big-blow-to-booming-hotelindustry/436087/

18. Www.hvs.com/article/5728/hotel-room-supply-capitalinvestment-and-manpower/ 
Figure 1 : Foreign Tourist Arrivals into India

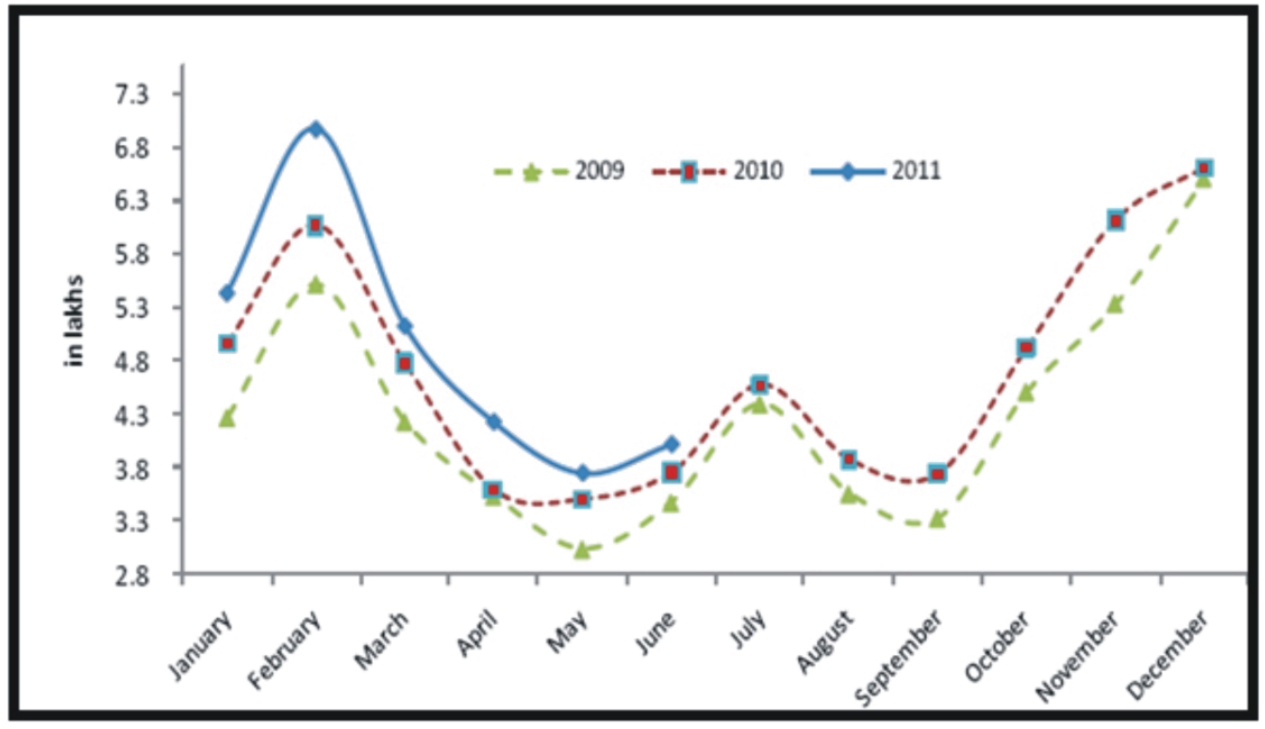

Source: Ministry of Tourism, Government of India, and ICRA's estimates

Table 1 : Travel \& Tourism Competitiveness Index 2011: Asia Pacific

\begin{tabular}{|lll|}
\hline Country & Regional Rank & Overall Rank \\
\hline Singapore & 1 & 10 \\
Hong Kong SAR & 2 & 12 \\
Australia & 3 & 13 \\
New Zealand & 4 & 19 \\
Japan & 5 & 22 \\
Korea, Rep. & 6 & 32 \\
Malaysia & 7 & 35 \\
Taiwan, China & 8 & 37 \\
China & 9 & 39 \\
Thailand & 10 & 41 \\
Brunei & 11 & 67 \\
India & 12 & 68 \\
Indonesia & 13 & 74 \\
Vietnam & 14 & 80 \\
Sri Lanka & 15 & 81 \\
Azerbaijan & 16 & 83 \\
Kazakhstan & 17 & 93 \\
Philippines & 18 & 94 \\
Mongolia & 19 & 101 \\
Kyrgyz Republic & 20 & 107 \\
Cambodia & 21 & 109 \\
Nepal & 22 & 112 \\
Tajikistan & 23 & 118 \\
Pakistan & 24 & 125 \\
Bangladesh & 25 & 129 \\
Timor-Leste & 26 & 134 \\
\hline
\end{tabular}

Source: The Travel \& Tourism Competitiveness Index 2011: Asia Pacific 
Table 2 : Demand \& Supply of Manpower in Indian Hospitality Industry

\begin{tabular}{|c|c|c|c|c|c|c|}
\hline & Luxury & First class & Mid-Market & Budget & Extended Stay & Total \\
\hline Aditional Rooms Required by 2021 & 21,181 & 37,834 & 70,761 & 45,810 & 4,540 & $1,80,133$ \\
\hline Manpower to Room Ratio & 2.70 & 2.11 & 1.52 & .72 & 1.50 & \\
\hline \multicolumn{7}{|c|}{ Ratio Breakdown } \\
\hline Managers & .35 & .26 & .19 & .09 & .18 & \\
\hline Supervisors & .30 & .28 & .20 & .13 & .20 & \\
\hline Associates & 2.05 & 1.57 & 1.13 & .51 & 1.12 & \\
\hline Additional Manpower required by 2021 & 57206 & 79831 & 107556 & 32983 & 6810 & 284366 \\
\hline \multicolumn{7}{|c|}{ Manpower Breakdown } \\
\hline Managers & 7458 & 9807 & 13378 & 4102 & 837 & 35582 \\
\hline Supervisors & 6265 & 10592 & 13913 & 5743 & 904 & 37416 \\
\hline Associates & 43482 & 59432 & 80266 & 23138 & 5070 & 211387 \\
\hline
\end{tabular}

Source: 2011 Indian Hotel Industry Manpower Survey, HVS 